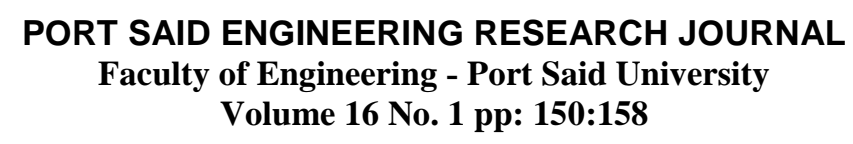

\title{
Design of High Strength Concrete (HSC) Using North Sinai Materials
}

\author{
M.S.Fattouh $^{1}$, K. Sharobim ${ }^{2}$, N. Hussien ${ }^{3}$, and H. Mokhtar ${ }^{4}$
}

\begin{abstract}
The use of high strength concrete in building systems is increased all over the world. This research presents the production of high strength concrete using local materials available in north Sinai area. All concrete ingredients (cement, water, fine and coarse aggregates in addition to admixtures) were subject to the requirements of the Egyptian standard specifications. Compressive strength, indirect tensile strength, flexural strength, and permeability tests were conducted on the concrete. In this research, 27 concrete mixes were made with cement content 400,450 and $500 \mathrm{Kg} / \mathrm{m}^{3}$. One type of Beir El-bd sand is used as fine aggregate and three types of coarse aggregates basalt, dolomite and gravel are used in high strength concrete mixtures. Silica fume was used with a dosage of $(0,10,15) \%$ of cement content, and also high water range reducer superplasticizer with a dosage of (0 and 3) \% of the binder content. To achieve compressive strength greater than $500 \mathrm{~kg} / \mathrm{cm}^{2}$ at the age of 28 days. As a result, concrete mix containing a dolomite 15\% silica fume with 3\% superplasticizer produced a compressive strength of $950 \mathrm{~kg} / \mathrm{cm}^{2}$ and low permeability of $1.6 \times 10{ }^{-9} \mathrm{~cm}^{3} / \mathrm{sec}$. The use of lower amount of cement content, silica fume and superplasticizer gives lower strength and high permeability. Analyzing the results of this research produce a design that describes compressive strength-silica fume relationship curves and compressive strength-superplasticizer content relationship.
\end{abstract}

Key words:-high strength concrete, silica fume, compressive strength, indirect tensile strength, flexure strength.

\section{INTRODUCTION}

Sinai Peninsula runs along the north-east of Egypt with a total area of about 61,000 square Kilometers. The importance of North Sinai mountains to construction, such as granite, basalt, limestone, and crushed stone and gravel in addition to the presence of sand which is used in the work of concrete in Sinai ${ }^{[1]}$

The study area extends along North Sinai Peninsula plain which is considered an integral part of the Mediterranean Sea. This paper leads to a better understanding of the effect of aggregate type on the mechanical behaviour of high strength concrete and a trial to produce high strength concrete from these available materials.

ACI committee 363 on HSC, in its 1997 report has specified compressive strengths

\footnotetext{
1 Civil Engineering Department, high institute for engineering and technology, North Sinai, Egypt

E-mail: $\underline{\text { m_fattouh3@hotmail.com }}$

2 Prof. of Civil Engineering Department, Faculty of Engineering, Suez Canal University, Ismailia, Egypt,

E-mail: k.sharobim@scuegypt.edu.eg

3 Civil Engineering Department, Faculty of Engineering, Suez Canal University, Ismailia, Egypt,

E-mail: elsaidy2000@ hotmail.com
}

\footnotetext{
${ }^{4}$ Civil Engineering Department, Faculty of Engineering, Port Said University, Port Said, Egypt,

E-mail: Nourallah@ psu.edu.eg.
}

for design of $6000 \mathrm{psi}$ (41 MPa) or greater, but for the present time, considerations shall not include concrete made using exotic materials or techniques. ${ }^{2]}$

The FIP/CEB defines HSC as "a concrete having a minimum 28 -day compressive strength $60 \mathrm{MPa}$. Due to its fine microstructure, HSC possesses different mechanical properties compared to normal strength concrete. [3] In the 1950's, concrete with a compressive strength of 5000 Psi (34 MPa) was considered high strength. In the early 1970's, 9000 Psi (62 MPa) concrete was produced. More recently, compressive strengths approaching 20,000 Psi (138 MPa) have been used in cast-in-place buildings. ${ }^{[4]}$

The high compressive strength can be used advantageously in compression members such as columns and piles. In columns, the reduction in size will lead to reduced dead load and subsequently will reduce total load on the foundation system. ${ }^{[5]}$ 
The map given in fig.(1) shows the locations of dolomite rocks in north Sinai. ${ }^{[1]}$ There are dolomite rocks as show in fig 1 with large quantity, either alone or associated with layers of limestone and rock. Dolomite rocks are characterized by high resistance to severe weather, pressure, and the proportion of the magnesium oxide from $13 \%$ to $20.5 \%$. Dolomite rocks are used to pave roads and in concrete and stone construction. ${ }^{[1]}$

Although some design specifications have addressed the use of HSC, many have implicitly or explicitly placed restriction on its use, primarily because of limited research data. ${ }^{[6]}$

Extensive experimental investigations by Entroy and Shacklock ${ }^{[7]}$ have indicated that in high strength concrete mixes, workability, type and maximum size of aggregate and the strength requirements, influence the selection of the water/cement ratio. The increase of tensile strength affects the increase of compressive strengths. There is a decrease, however, in the ratio of tensile to compressive strength as compressive strength increases. ${ }^{[8]}$

French et al. (1993) ${ }^{[9]}$ observed in their study that $100 \times 200 \mathrm{~mm}$ cylinders tested showed 6 percent higher strength than that of their companion $150 \mathrm{x}$ $300 \mathrm{~mm}$ cylinders. Aïtcin et al. (1994) [10] reported that larger cylinder sizes gave rise to lower apparent compressive strength, and that compressive strength is not sensitive to cylinder size for very high strength concrete. The relationship between the ratio of splitting tensile strength to compressive strength (ftsp/fc) and cylinder compressive strength (fc), which are applicable to concrete at early ages (12 hours and longer) as well as very high strength concrete up to $1224 \mathrm{~kg} / \mathrm{cm}^{2}$ are influenced by the level of concrete strength. ${ }^{[11]}$

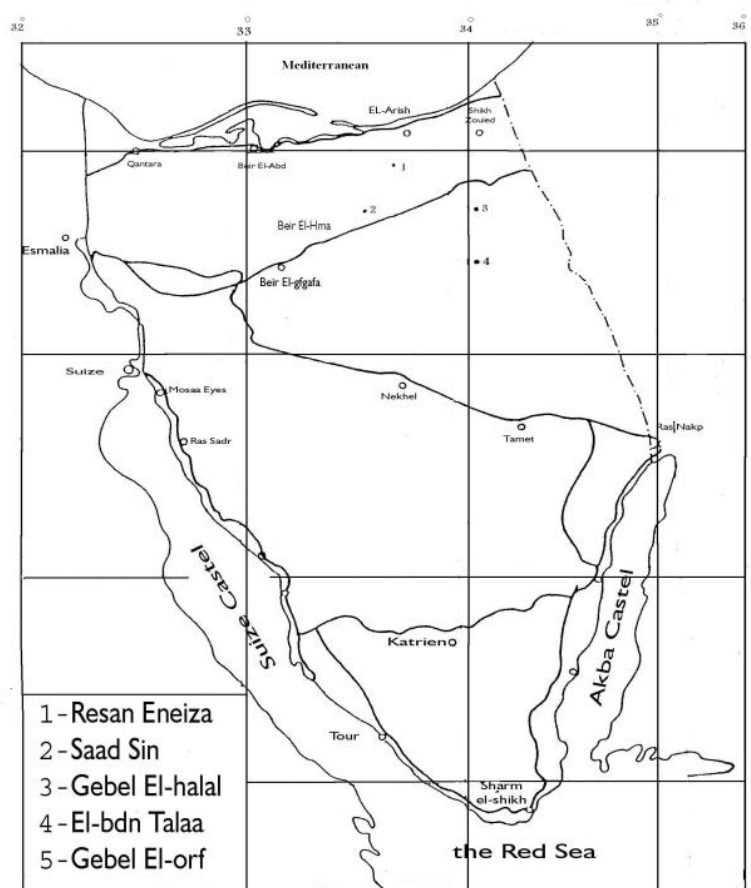

Fig 1: locations of dolomite rocks in the Sinai

The State-of -the report on high-strength concrete ${ }^{[2]}$ reported that silica fume has been used in highstrength concretes for structural purposes.

There is no exact method for determining the required superplasticizer dosage. When achieving strength considered as the primary criterion, it should be with the lowest water-cement ratio, and the highest superplasticizer rate. ${ }^{[4]}$

\section{Experimental work}

Experimental work using local resources of North Sinai materials was conducted to produce high strength concrete.

Figure 2 shows the difference between two types of North Sinai fine aggregates and the results indicated that Beir El-Abd sand is rougher than ElArish sand and both are in the range of the specifications, according to the Egyptian code of concrete laboratory and tests, [12] and ASTM C136 specifications [13]: 


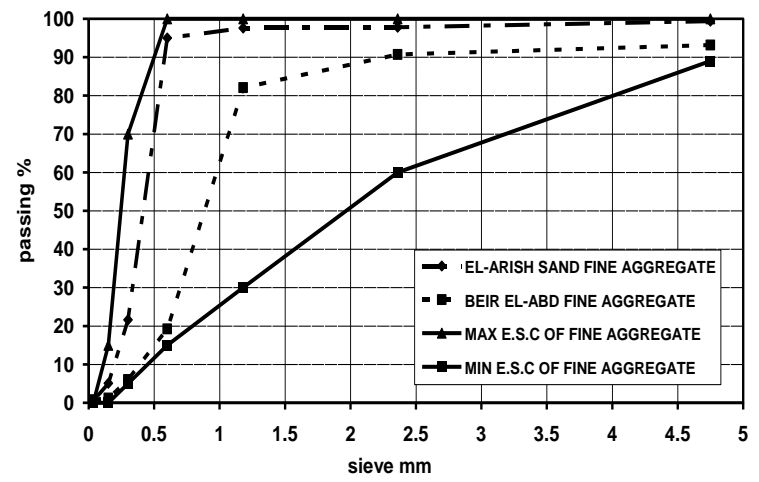

Figure 2: sieve analysis curves of fine aggregates in North Sinai

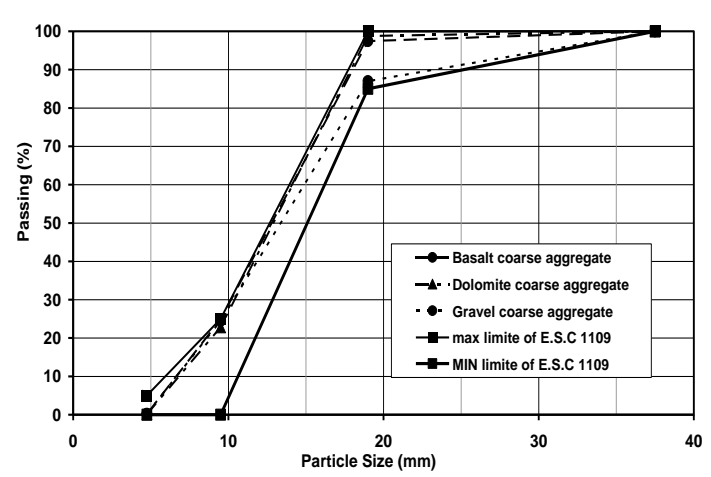

Fig 3 the particle size distribution of three types of North Sinai course aggregates.

The specific gravity was determined according to ASTM $^{[14]}$ and list in Tables $(1,2)$.

Table 1: specific gravity of coarse aggregate according to Egyptian standards:

\begin{tabular}{|c|c|c|}
\hline $\begin{array}{c}\text { North Sinai coarse } \\
\text { aggregate }\end{array}$ & Average & $\begin{array}{c}\text { Egyptian } \\
\text { standards }\end{array}$ \\
\hline Dolomite & 2.70 & $2.6-2.7$ \\
\hline Basalt & 2.66 & $2.6-2.8$ \\
\hline Gravel & 2.60 & $2.5-2.7$ \\
\hline
\end{tabular}

Table 2: the specific gravity of North Sinai fine aggregate according to Egyptian standards:

\begin{tabular}{|c|c|c|}
\hline Fine Aggregate & Specific gravity & Egyptian code \\
\hline El-arish sand & 2.55 & $2.5-2.75$ \\
\hline Ber El-abd sand & 2.57 & $2.5-2.75$ \\
\hline
\end{tabular}

Table 3: mix proportion using different types of North Sinai aggregates with $\mathrm{W} / \mathrm{C} 0.3$, cement content $\cdots \cdot \mathrm{kg} / \mathrm{m}^{3}$.

\begin{tabular}{|c|c|c|c|c|c|c|}
\hline Batch no & $\begin{array}{c}\text { Coarse } \\
\text { aggregate } \\
\text { type }\end{array}$ & $\begin{array}{c}\text { Coarse } \\
\text { aggregate } \\
\mathrm{kg} / \mathrm{m}^{3}\end{array}$ & $\begin{array}{c}\text { sand } \\
\mathrm{kg} / \mathrm{m}^{3}\end{array}$ & $\% \mathrm{SF}$ & $\% \mathrm{SP}$ & $\begin{array}{c}\text { Slump } \\
(\mathrm{cm})\end{array}$ \\
\hline P1 & Basalt & 1223.7 & 578.12 & $0 \%$ & $0 \%$ & 11 \\
\hline P2 & Basalt & 1158.5 & 547.3 & $10 \%$ & $3 \%$ & 9 \\
\hline P3 & Basalt & 1146.4 & 541.6 & $15 \%$ & $3 \%$ & $\wedge$ \\
\hline P4 & Dolomite & 1235.3 & 584.39 & $0 \%$ & $0 \%$ & $\circ$ \\
\hline P5 & Dolomite & 1170 & 552.7 & $10 \%$ & $3 \%$ & 9 \\
\hline P6 & Dolomite & 1157.8 & 547 & $15 \%$ & $3 \%$ & $\vee, 0$ \\
\hline P7 & Gravel & 1237 & 583 & $0 \%$ & $0 \%$ & $\circ, 0$ \\
\hline P8 & Gravel & 1081 & 510 & $10 \%$ & $3 \%$ & 9 \\
\hline P9 & Gravel & 1159 & 546 & $15 \%$ & $3 \%$ & $\wedge$ \\
\hline
\end{tabular}

Table 4: mix proportion using different types of North Sinai aggregates with W/C 0.3 , cement content $45 \cdot \mathrm{kg} / \mathrm{m}^{3}$.

\begin{tabular}{|c|c|c|c|c|c|c|}
\hline Batch no & $\begin{array}{c}\text { Coarse } \\
\text { aggregate } \\
\text { type }\end{array}$ & $\begin{array}{c}\text { Coarse } \\
\text { aggregate } \\
\mathrm{kg} / \mathrm{m}^{3}\end{array}$ & $\begin{array}{c}\text { sand } \\
\mathrm{kg} / \mathrm{m}^{3}\end{array}$ & $\% \mathrm{SF}$ & $\% \mathrm{SP}$ & $\begin{array}{c}\text { Slump } \\
(\mathrm{cm})\end{array}$ \\
\hline P10 & Basalt & 1278.31 & 603.9 & $0 \%$ & $0 \%$ & 11 \\
\hline P11 & Basalt & 1219.7 & 576.2 & $10 \%$ & $3 \%$ & $\wedge$ \\
\hline P12 & Basalt & 1208.8 & 571.1 & $15 \%$ & $3 \%$ & $\wedge$ \\
\hline P13 & Dolomite & 1290.45 & 610.5 & $0 \%$ & $0 \%$ & $\mathrm{Ir}$ \\
\hline P14 & Dolomite & 1231.8 & 582 & $10 \%$ & $3 \%$ & $\mathrm{\Upsilon}, 0$ \\
\hline
\end{tabular}




\begin{tabular}{|c|c|c|c|c|c|c|}
\hline P15 & Dolomite & 1221 & 576.8 & $15 \%$ & $3 \%$ & $\vee, 0$ \\
\hline P16 & Gravel & 1292.21 & 607.86 & $0 \%$ & $0 \%$ & Ir \\
\hline P17 & Gravel & 1152.4 & 543 & $10 \%$ & $3 \%$ & $\wedge$ \\
\hline P18 & Gravel & 1222 & 575.7 & $15 \%$ & $3 \%$ & $\wedge$ \\
\hline
\end{tabular}

Table 5: mix proportion using different types of North Sinai aggregates with W/C 0.3, cement content $40 \cdot \mathrm{kg} / \mathrm{m}^{3}$.

\begin{tabular}{|c|c|c|c|c|c|c|}
\hline Batch no & $\begin{array}{c}\text { Coarse } \\
\text { aggregate } \\
\text { type }\end{array}$ & $\begin{array}{c}\text { Coarse } \\
\text { aggregate } \\
\mathrm{kg} / \mathrm{m}^{3}\end{array}$ & $\begin{array}{c}\text { sand } \\
\mathrm{kg} / \mathrm{m}^{3}\end{array}$ & $\% \mathrm{SF}$ & $\% \mathrm{SP}$ & $\begin{array}{c}\text { Slump } \\
(\mathrm{cm})\end{array}$ \\
\hline P19 & Basalt & 1333 & 630 & $0 \%$ & $0 \%$ & 5 \\
\hline P20 & Basalt & 1285.3 & 607.2 & $10 \%$ & $3 \%$ & $1 \Sigma$ \\
\hline P21 & Basalt & 1271.2 & 600.5 & $15 \%$ & $3 \%$ & 1 r \\
\hline P22 & Dolomite & 1345 & 635.6 & $0 \%$ & $0 \%$ & T \\
\hline P23 & Dolomite & 1298.1 & 614 & $10 \%$ & $3 \%$ & 10 \\
\hline P24 & Dolomite & 1283.8 & 606.5 & $15 \%$ & $3 \%$ & $1 \leq$ \\
\hline P25 & Gravel & 1347.5 & 634.9 & $0 \%$ & $0 \%$ & 7 \\
\hline P26 & Gravel & 1299.3 & 612.2 & $10 \%$ & $3 \%$ & 11 \\
\hline P27 & Gravel & 1285 & 605.5 & $15 \%$ & $3 \%$ & 9 \\
\hline
\end{tabular}



According to Egyptian code ${ }^{[12]}$ the abrasion resistance of coarse aggregates in los Angeles machine doesn't exceed about $20 \%$ for gravel and $30 \%$ for crushed stone (dolomite and basalt). A Sample of aggregate retained on No $9.5 \mathrm{~mm}$ sieve is placed inside a rotating steel drum .The test results of north Sinai coarse aggregates are shown in the following table.

Table 6: abrasion resistance percentage of coarse aggregates:

\begin{tabular}{|l|l|}
\hline North Sinai coarse aggreagte & abrasion resistance\% \\
\hline
\end{tabular}

\begin{tabular}{|c|c|}
\hline Dolomite & $0.097 \%$ \\
\hline Basalt & $0.069 \%$ \\
\hline Gravel & $0.017 \%$ \\
\hline
\end{tabular}

As illustrated in Table 7, the mechanical properties of north Sinai cement shows the compressive strength, initial and final setting time used in this research.

Table 7: Mechanical properties of Sinai cement:

\begin{tabular}{|c|c|c|c|}
\hline \multicolumn{2}{|c|}{ Test } & $\begin{array}{c}\text { Sinai } \\
\text { cement }\end{array}$ & $\begin{array}{c}\text { Egyptian } \\
\text { specifications }\end{array}$ \\
\hline $\begin{array}{c}\text { Compressive } \\
\text { strength } \\
\mathrm{kg} / \mathrm{cm} 2\end{array}$ & 7day & $410: 430$ & 270 \\
\cline { 2 - 4 } & 28day & $530: 560$ & 360 \\
\hline \multicolumn{2}{|c|}{ Initial setting time(min) } & $110: 150$ & $>45$ \\
\hline \multicolumn{2}{|c|}{ Final setting time(hr) } & $2.5: 3$ & $<10$ \\
\hline \multicolumn{2}{|c|}{ Fineness $\left(\mathrm{gm} / \mathrm{cm}^{2}\right)$} & $3300 \pm 100$ & $>2500$ \\
\hline
\end{tabular}

The coarse aggregate was washed, the fine and coarse aggregate moisture contents were measured prior to mixing. superplasticizer was considered in proportioning, with mix water cement ratio 0.30 attained for the next concrete mixes. The curing ages mixtures to produce high strength are 3,7 , and 28 days for compression strength, curing ages 7 and 28 days for the indirect tensile strength and Curing ages 28 and 56 for the flexure strength .

According to ASTM C192 ${ }^{[15]}$,the test specimens for the high strength concrete were $(15 \times 15 \times 15)$ concrete cubes, $(15 \times 30)$ cylinders, $(10 \times 10 \times 50 \mathrm{~mm})$ beams.

Permeability test for the concrete mixtures were performed. Table (8) shows the results of permeability test with dolomite, basalt and gravel. permeability test were conducted to Batches P3,P6, and P9 using (500 $\mathrm{kg} / \mathrm{m}^{3}$ cement content, $15 \%$ silica fume (S.F) , 3\% superplasticizer (PC) of cement content shown in Table (4).

Table 8: result of permeability

\begin{tabular}{|c|c|c|}
\hline Mix no & $\begin{array}{c}\text { Coarse } \\
\text { aggregate }\end{array}$ & $\mathrm{K}(\mathrm{cm} / \mathrm{sec})$ \\
\hline P3 & Basalt & $1.2 \times 10^{-12}$ \\
\hline P6 & Dolomite & $1.35 \times 10^{-10}$ \\
\hline P9 & Gravel & $1.12 \times 10^{-11}$ \\
\hline
\end{tabular}

\section{Results}

3.1- The mechanical properties of the concrete mixes were shown in table $(9,10,11)$

high strength concrete mixtures results using Beir El-Abd sand and North Sinai coarse aggregates with water cement ratio $(\mathrm{w} / \mathrm{c})=0.3$, cement content 400,450 and $500 \mathrm{~kg} / \mathrm{m}^{2}$, silica fume, superplasticizer as a percentages with cement content as shown in experimental work are shown in Tables $(3,4$ and 5$)$.

Table 9: results of the mix proportion using different types of

North Sinai aggregates with W/C 0.3, and cement content 50 .

$\mathrm{kg} / \mathrm{m}^{3}$.

\begin{tabular}{|c|c|c|c|c|c|c|c|}
\hline $\begin{array}{c}\text { Batch } \\
\text { No }\end{array}$ & \multicolumn{3}{|c|}{$\begin{array}{c}\text { Compressive } \\
\text { strength } \\
\left(\mathrm{kg} / \mathrm{cm}^{2}\right)\end{array}$} & \multicolumn{2}{c|}{$\begin{array}{c}\text { Indirect } \\
\text { tensile } \\
\text { strength } \\
\left(\mathrm{kg} / \mathrm{cm}^{2}\right)\end{array}$} & \multicolumn{2}{c|}{$\begin{array}{c}\text { Flexure } \\
\text { strength } \\
\left(\mathrm{kg} / \mathrm{cm}^{2}\right)\end{array}$} \\
\hline days & 3 & 7 & 28 & 7 & 28 & 28 & or \\
\hline P1 & 260 & 297 & 400 & 38.8 & 48 & 43 & 47 \\
\hline P2 & 475 & 590 & 780 & 56 & 62 & 80 & 102 \\
\hline P3 & 522 & 641 & 860 & 64 & 73 & 82 & 104 \\
\hline P4 & 253 & 331 & 484 & 44.7 & 54 & 44 & 49 \\
\hline P5 & 510 & 640 & 865 & 68 & 74 & 92 & 100 \\
\hline P6 & 529 & 702 & 945 & 69 & 83 & 96 & 108 \\
\hline P7 & 206 & 278 & 408 & 36.5 & 44 & 39 & 44 \\
\hline P8 & 384 & 540 & 710 & 52 & 54 & 56 & 74 \\
\hline P9 & 398 & 596 & 803 & 55 & 60 & 66 & 83 \\
\hline
\end{tabular}

Table 10: results of the mix proportion using different types of North Sinai aggregates with W/C 0.3, and cement content 45 . $\mathrm{kg} / \mathrm{m}^{3}$.

\begin{tabular}{|c|c|c|c|c|c|c|c|}
\hline $\begin{array}{c}\text { Batch } \\
\text { No }\end{array}$ & \multicolumn{3}{|c|}{$\begin{array}{c}\text { Compressive } \\
\text { strength } \\
\left(\mathrm{kg} / \mathrm{cm}^{2}\right)\end{array}$} & \multicolumn{2}{c|}{$\begin{array}{c}\text { Indirect } \\
\text { tensile } \\
\text { strength } \\
\left(\mathrm{kg} / \mathrm{cm}^{2}\right)\end{array}$} & \multicolumn{2}{c|}{$\begin{array}{c}\text { Flexure } \\
\text { strength } \\
\left(\mathrm{kg} / \mathrm{cm}^{2}\right)\end{array}$} \\
\hline days & 3 & 7 & 28 & 7 & 28 & 28 & ○7 \\
\hline P10 & 225 & 307 & 440 & 35.8 & 43.9 & 40.4 & 43.4 \\
\hline P11 & 474 & 575 & 753 & 48.1 & 58 & 76.8 & 94.8 \\
\hline P12 & 497 & 616 & 825 & 55.9 & 65.1 & 79.2 & 95.4 \\
\hline P13 & 240 & 320 & 470 & 41.7 & 50.2 & 40.7 & 46.4 \\
\hline P14 & 495 & 626 & 795 & 66.5 & 67.9 & 81 & 96 \\
\hline P15 & 502 & 675 & 855 & 67.9 & 73.2 & 82.8 & 98 \\
\hline P16 & 195 & 267 & 395 & 32.5 & 40.3 & 36.5 & 40.1 \\
\hline P17 & 435 & 545 & 689 & 45 & 50 & 53 & 58.6 \\
\hline P18 & 453 & 580 & 719 & 46 & 52 & 53.1 & 59.1 \\
\hline
\end{tabular}


Table 11: results of the mix proportion using different types of North Sinai aggregates with W/C 0.3, and cement content 40 . $\mathrm{kg} / \mathrm{m}^{3}$.

\begin{tabular}{|c|c|c|c|c|c|c|c|}
\hline $\begin{array}{c}\text { Batch } \\
\text { No }\end{array}$ & \multicolumn{3}{|c|}{$\begin{array}{c}\text { Compressive } \\
\text { strength } \\
\left(\mathrm{kg} / \mathrm{cm}^{2}\right)\end{array}$} & \multicolumn{2}{c|}{$\begin{array}{c}\text { Indirect } \\
\text { tensile } \\
\text { strength } \\
\left(\mathrm{kg} / \mathrm{cm}^{2}\right)\end{array}$} & \multicolumn{2}{c|}{$\begin{array}{c}\text { Flexure } \\
\text { strength } \\
\left(\mathrm{kg} / \mathrm{cm}^{2}\right)\end{array}$} \\
\hline days & 3 & 7 & 28 & 7 & 28 & 28 & 07 \\
\hline P19 & 195 & 265 & 364 & 22.6 & 34 & 35 & 41.2 \\
\hline P20 & 390 & 507 & 685 & 36.8 & 47.5 & 48 & 54 \\
\hline P21 & 426 & 553 & 692 & 45.3 & 56.6 & 52.8 & 58.8 \\
\hline P22 & 189 & 280 & 385 & 34 & 40.5 & 40.3 & 42.3 \\
\hline P23 & 390 & 537 & 691 & 42.5 & 51 & 52 & 72 \\
\hline P24 & 383 & 476 & 714 & 44.6 & 53.8 & 51.2 & 57.9 \\
\hline P25 & 175 & 240 & 340 & 19.8 & 29 & 28 & 36 \\
\hline P26 & 340 & 471 & 630 & 34 & 38.9 & 35.10 & 42 \\
\hline P27 & 371 & 571 & 618 & 38.2 & 46.7 & 40 & 50 \\
\hline
\end{tabular}

\section{2-Results of the cubes, cylinders, and flexure beam strength.}

Curves show that compressive strength values increased due to cement content and curing ages increase. As shown in Figure (5) for 28 days curing age $\mathrm{a}\left(945 \mathrm{~kg} / \mathrm{cm}^{2}\right)$ strength value in $\mathrm{P} 4$ using dolomite coarse aggregates is higher than the value ( 860 $\left.\mathrm{kg} / \mathrm{cm}^{2}\right)$ in P1 using basalt coarse aggregates as shown in Figure (4). But in P7 using gravel coarse aggregates value of the strength $\left(803 \mathrm{~kg} / \mathrm{cm}^{2}\right)$ is lower than values in P1, P4 as shown in Figure (6).

Also, indirect tensile and flexure strength values in Batch (4) are (83) and (108) $\mathrm{kg} / \mathrm{cm}^{2}$ ) respectively using dolomite which is higher than the others.

The results indicated that the mechanical properties of dolomite north Sinai coarse aggregates is better than both basalt and gravel. Using the same cement content $500 \mathrm{Kg} / \mathrm{m}^{3}$, w/c=0.3, $15 \%$ silica fume and superplasicizer with Beir El-Abd sand and changing cement content from 500 to 450 and $400 \mathrm{Kg} / \mathrm{m}^{3}$, with $\mathrm{w} / \mathrm{c}=0.3,15 \%$ silica fume, superplasicizer with Beir ElAbd sand gave the same results shown in tables 10,11.

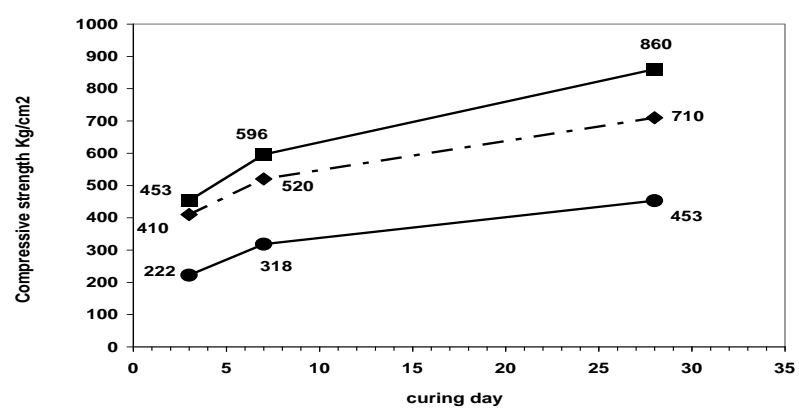

Fig 4: Relation between compressive strength \& curing age at $3,7,28$ days $W / C=0.3, C C=500 \mathrm{Kg} / \mathrm{m}^{3}$ of Basalt with Beir $\mathrm{El}-\mathrm{Abd}$ sand

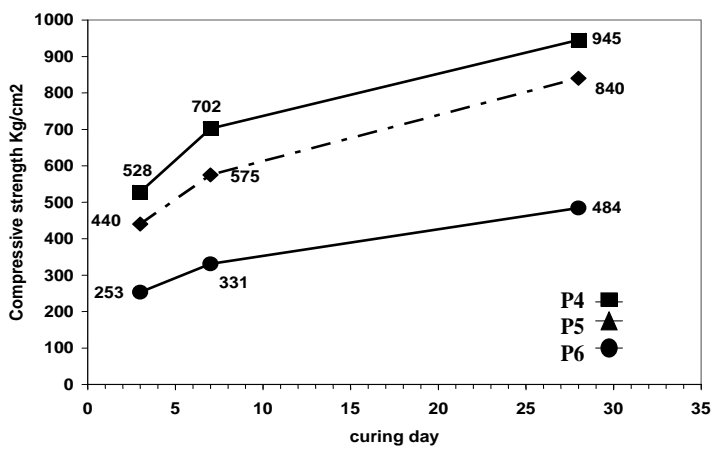

Fig 5: Relation between compressive strength \& curing age at $3,7,28$ days $W / C=0.3, C C=500 \mathrm{Kg} / \mathrm{m}^{3}$ of Dolomite with Beir El-Abd sand

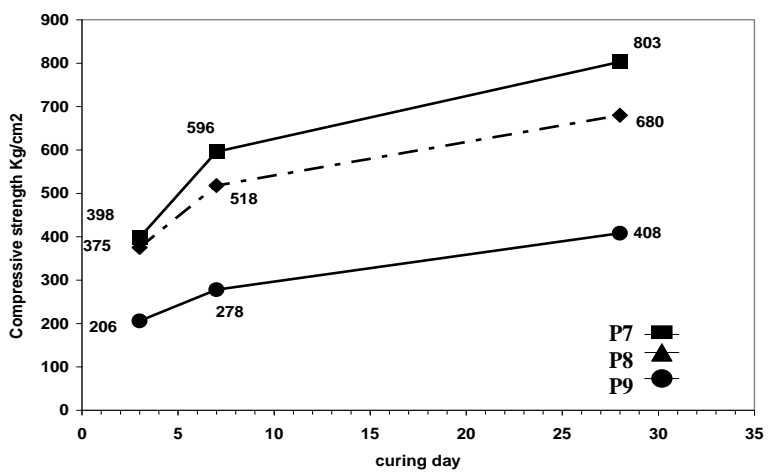

Fig 6: Relation between compressive strength \& curing age at $3,7,28$ days $W / C=0.3, C C=500 \mathrm{Kg} / \mathrm{m}^{3}$ of Gravel with Beir El-Abd sand

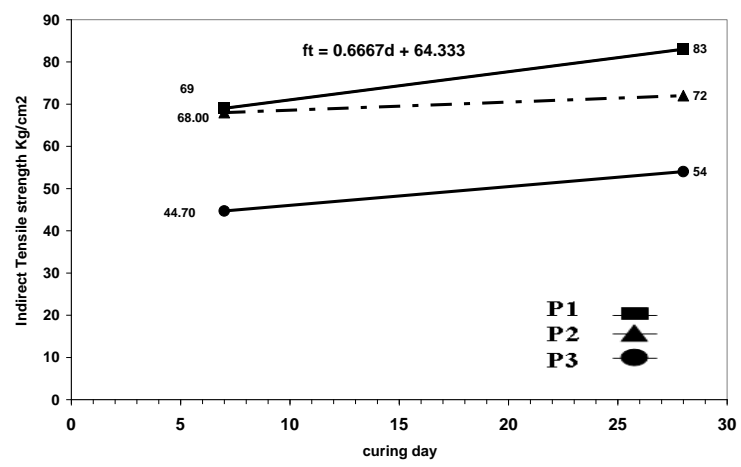

Fig 7: Relation between Indirect Tensile strength \&curing age at 7, 28 days $W / C=0.3, C C=500 \mathrm{Kg} / \mathrm{m}^{3}$ of Dolomite with Beir El-Abd sand

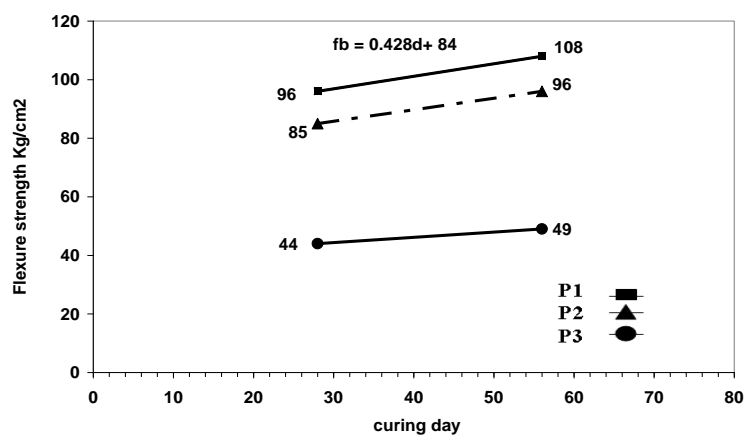

Fig 8: Relation between flexure strength \&curing age at 28, 56 days $\mathrm{W} / \mathrm{C}=0.3, \mathrm{CC}=500 \mathrm{Kg} / \mathrm{m}^{3}$ of Dolomite with Beir El-Abd sand 
Figures 9.10.11and 15show relation between compressive strength and silica fume with cement content 500,450 , and $400 \quad \mathrm{Kg} / \mathrm{m}^{3}$ respectively .The results show the effects on compressive strength of using different amounts of cement content, silica fume, and water cement ratio in high strength concrete using north Sinai materials. The curves that are shown are typical of what may be expected. The very important point in these figures are:

The ratio of 3-day or 7-day strength to 28-day strength is reasonably consistent, regardless of the 28-day strength achieved. The ratio of $15 \%$ silica fume content to cement ratio achieve a higher strength concrete in dolomite than in basalt and gravel aggregates. It is clear that the results of curves are close to each other of basalt and gravel in Figure 9.while the results of curves are close to each other of dolomite and basalt in figure 10 and 11 respectively.

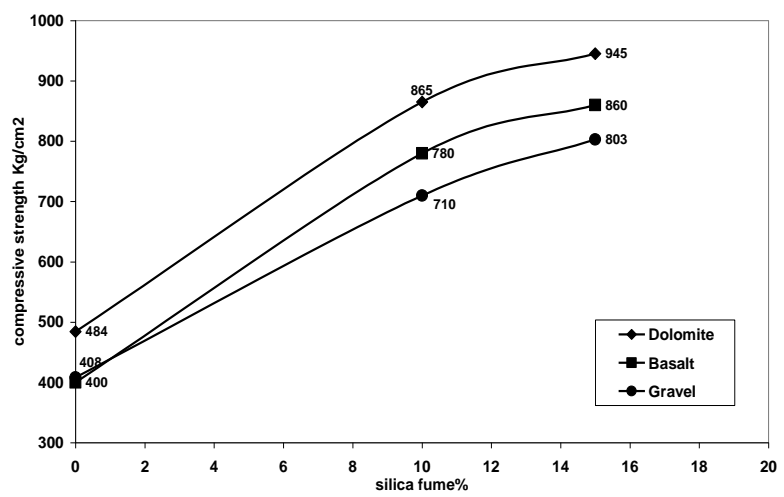

Fig 9: Relation between compressive strength and silica fume at 28 days $W / C=0.3,3 \%$ superplastisizer and $C C=500 \mathrm{Kg} / \mathrm{m}^{3}$ with Beir El-Abd sand

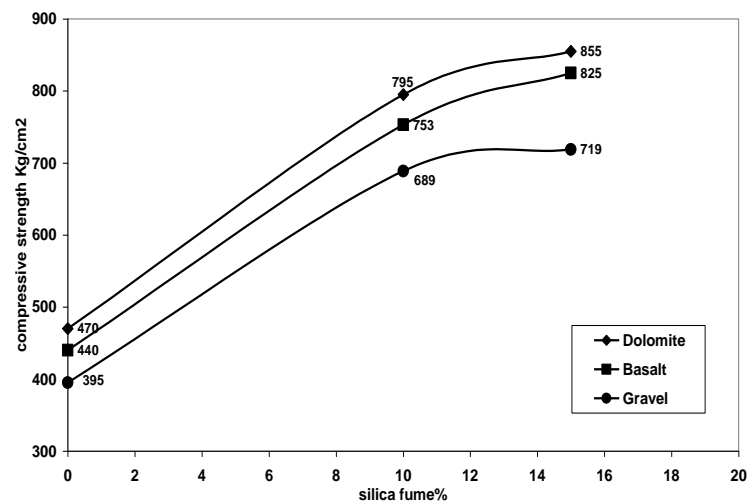

Fig 10: Relation between compressive strength and silica fume at 28 days $\mathrm{W} / \mathrm{C}=0.3,3 \%$ superplastisizer and $C \mathrm{C}=450 \mathrm{Kg} / \mathrm{m}^{3}$ with Beir El-Abd sand

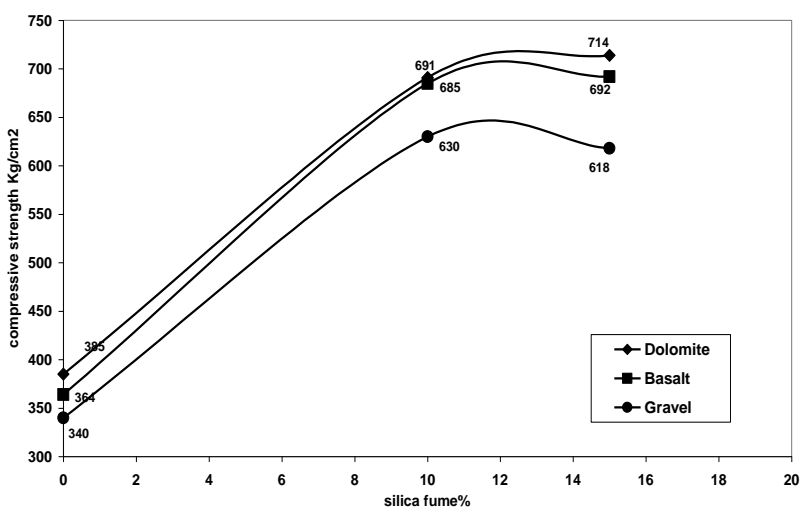

Fig 11: Relation between compressive strength and silica fume at 28 days $\mathrm{W} / \mathrm{C}=0.3,3 \%$ superplastisizer and $C \mathrm{C}=400 \mathrm{Kg} / \mathrm{m}^{3}$ with Beir El-Abd sand

In Figure 12, 13 and 14 it is observed that dolomite gave higher compressive strength, indirect tensile strength and flexure strength than basalt and gravel. The indirect tensile strength is affected by the changes of the compressive strength. Indirect tensile strength and compressive strength in mixtures P3, P6 and P9 is higher than other mixtures as shown in the figures. On the other hand, the effect of compressive strength, on indirect tensile strength and flexure strength using 500 $\mathrm{Kg} / \mathrm{cm}^{2}$ cement Content in mixtures from P1 to P 9 is more than mixtures using $450 \mathrm{Kg} / \mathrm{cm}^{2}$ and $400 \mathrm{Kg} / \mathrm{cm}^{2}$ cement content.

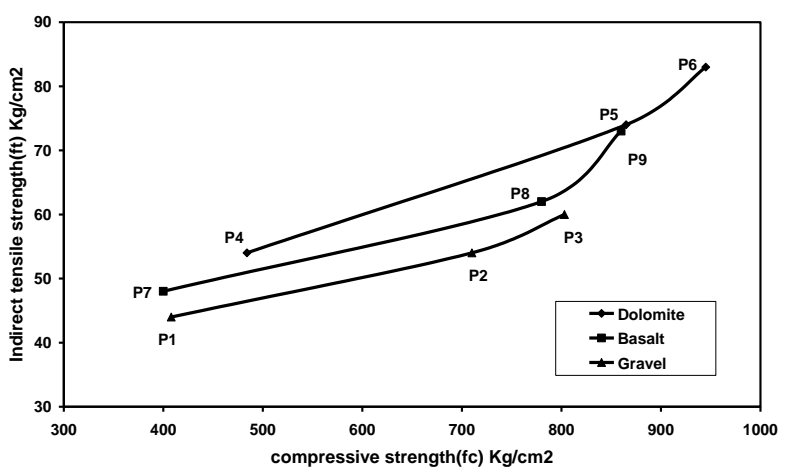

Fig 12: Relation between compressive strength and indirect tensile strength

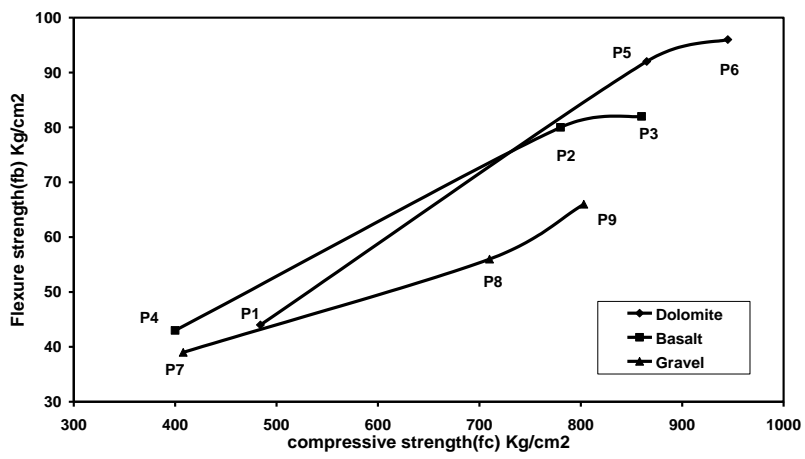

Fig 13: Relation between compressive strength and flexure strength 


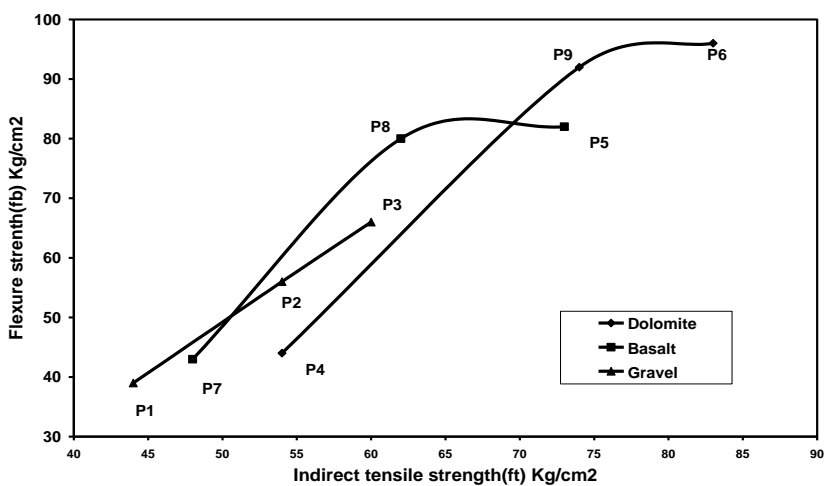

Fig 14: Relation between indirect tensile strength and flexure strength.

3.3- HSC design procedure using north Sinai materials Design the concrete mix required for high strength concrete using North Sinai materials:

Step (1) Type I cement having a bulk specific gravity of 3.15 is used.

Step (2) to determine the average compressive strength of the concrete mix to be designed:

applying the control factors to the minimum compressive strength .The required average strength used for selection of concrete proportion from the equation $^{[12]}$ :

$\mathrm{Fcr}=(\mathrm{fcu}+98) / 0.90 \mathrm{~kg} / \mathrm{m}^{3}$

Then find the suitable cement content from Fig 15 when using Beir El-Abd sand

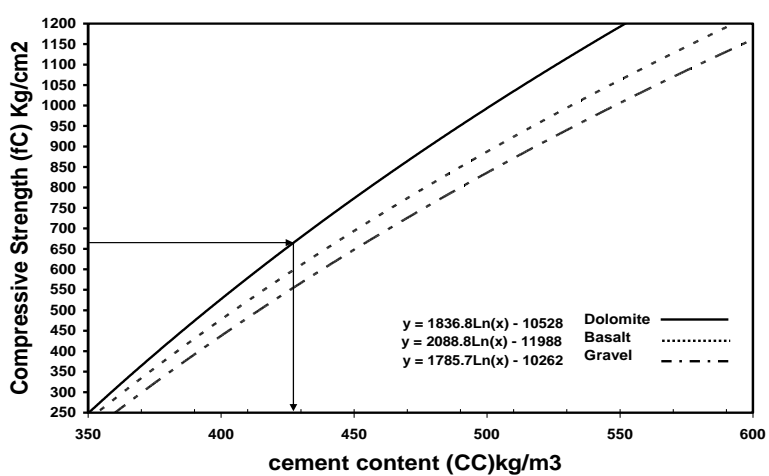

Fig 15: relation between compressive strength using Beir El-Abd sand and cement content $500 \mathrm{Kg} / \mathrm{m}^{3}$

Step (3) choose the w/c ratio to be 0.3 to achieve a high strength concrete using North Sinai materials

Step (4) select the suitable amount of silica fume percentage using relation between compressive strength and cement content as shown in Figures 16,17 and 18 as follows:

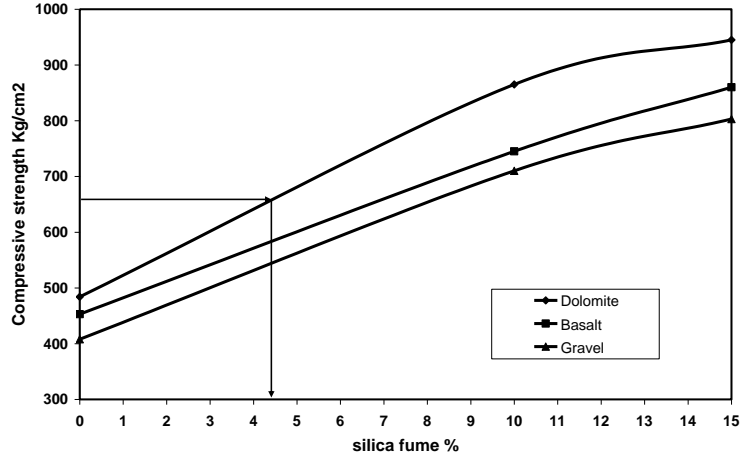

Fig 16: Relation between compressive strength and silica fume, $C C=500 \mathrm{Kg} / \mathrm{m3}, w / \mathrm{c}=0.3 \mathrm{Beir} \mathrm{El}$-Abd sand

Steps (5) select the suitable amount of super plasticizer percentage.

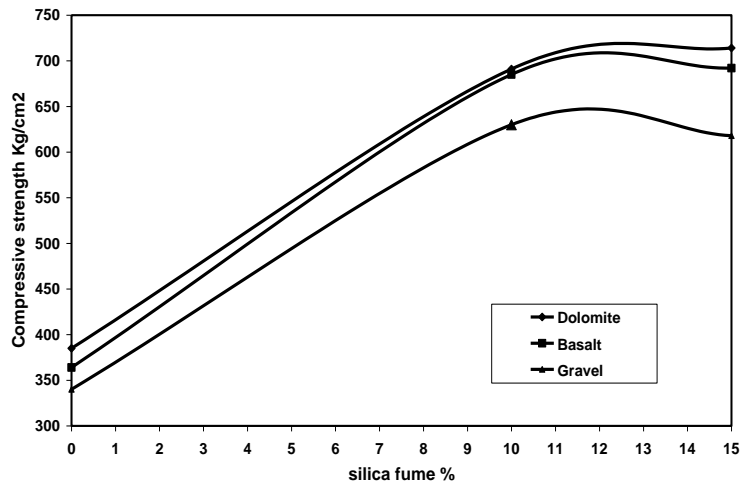

Fig 17: Relation between compressive strength and silica fume, $C C=450 \mathrm{Kg} / \mathrm{m3}, w / c=0.3 \mathrm{Beir}$ El-Abd sand

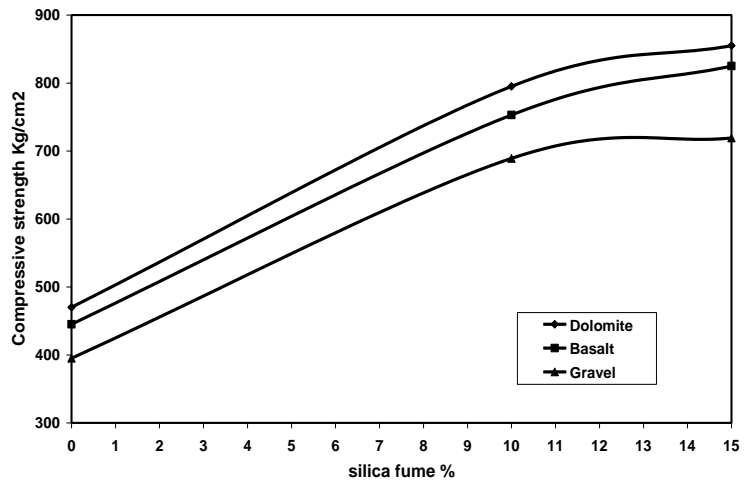

Fig18: Relation between compressive strength and silica fume, $C C=400 \mathrm{Kg} / \mathrm{m3}, w / c=0.3 \mathrm{Beir}$ El-Abd sand

Step (6) it is suggested that sand content is to be calculated by absolute volume method.

Table 12: Volume of coarse aggregate per unit volume of concrete

\begin{tabular}{|c|c|c|c|}
\hline $\begin{array}{c}\text { Maximum } \\
\text { size of } \\
\text { aggregate } \\
(\mathrm{cm})\end{array}$ & \multicolumn{3}{|c|}{$\begin{array}{c}\text { Volume of dry-roded coarse aggregate } \\
\text { per unit volume of concrete for } \\
\text { different finesse modulus of sand }\end{array}$} \\
\hline C.A & Dolomite & Basalt & Gravel \\
\hline $\begin{array}{c}\text { Specific } \\
\text { gravity }\end{array}$ & Y, & Y, 7 r & r, \\
\hline 1 & 0.46 & 0.57 & 0.59 \\
\hline 1.25 & 0.55 & 0.64 & 0.66 \\
\hline
\end{tabular}


Example, High strength concrete is to be proportioned for a high rise structure that will not be exposed to freezing and thawing using North Sinai materials. The designer did not require any air entrained contain in concrete.

(a) Assume $600 \mathrm{~kg} / \mathrm{cm}^{2}$ concrete strength required, substituting in Equation 5.1, the average strength used is $665 \mathrm{~kg} / \mathrm{cm}^{2}$ as step 2. The cement content is $4 \mathrm{r}^{\mathrm{o}}$ $\mathrm{Kg} / \mathrm{m}^{3}$ obtained from Fig 15

(b) A water cement ratio of $0.3 \mathrm{w} / \mathrm{c}$ will be used in the concrete mix design and equals to $156 \mathrm{~kg} / \mathrm{m} 3$.

(c) Using Figure 16 to get $4.5 \%$ silica fume and $2 \%$ super plasticizer of cement content, they are equal to 19.12 and $8.5 \mathrm{~kg} / \mathrm{m}^{3}$ respectively.

(d) Job conditions indicate that dolomite coarse aggregate with a maximum size of $2.5 \mathrm{~cm}$ to be 0.67 cubic meter on dry rodded basis per cubic meter of concrete. Therefore, the coarse aggregate content is $1000 \times 0.67=670 \mathrm{~kg} / \mathrm{m}^{3}$ The Beir El-Abd sand fine aggregate is natural sand of 2.5 specific gravity.

(f) The quantities of cement, fly ash, coarse aggregate, non-entrained air, and water having been established, the following absolute volumes of ingredients are:

$(425 / 3.15)+(19.12 / 2.20)+(8.5 / 1.1)+(670 / 2.7)+$

$(\mathrm{Ws} / 2.5)+(152 / 1)=1000 \ldots \ldots \ldots \ldots \ldots \ldots . . .(1)$

Solid volume of sand required $=\mathrm{m}^{3}$, so required weight

of dry sand $=448.52 \times 2.5=1121.30 \mathrm{~kg} / \mathrm{m}^{3}$

\section{CONCLUSION}

1. Effect of cement content and W/C ratio in HSC

The study shows that when the cement content was increased, the compressive strength can reach $(950$ $\mathrm{Kg} / \mathrm{cm}^{2}$ ) with dolomite coarse aggregates.

\section{Effect of silica fume ratio in HSC}

The concrete containing $15 \%$ silica fume produces higher compressive than that $10 \%$ silica fume at 3,7 days to 28 days curing age. The incorporation of silica fume in mixes resulted in finer pore structure thus produces low permeability concrete as that results indicated.

3 Effect of coarse and fine aggregate types in HSC

A series of tests were carried out to study the compressive, indirect tensile and flexure properties of HSC. The test results indicate that dolomite coarse aggregates represent the best of north Sinai coarse aggregates within the types studied, as long as silica fume and super plasticizer, are used.

\section{5- Recommendations}

Further testing and studies on North Sinai aggregate concrete is highly recommended to indicate the strength characteristics of North Sinai aggregates for application in high strength concrete.

It is recommended that testing can be done on concrete slabs, beams, and more trials with different particle sizes of North Sinai aggregates and percentage of replacement of North Sinai aggregates are recommended using steps and curves design in results sheet to get different outcomes and higher strength characteristics in the N.S aggregate concrete.

NOTATION

HSC-High strength concrete

$A C I-A m e r i c a n$ concrete institute

$\mathrm{FIB} / \mathrm{CEB}$ -

W/c - water/cement

Mpa-Mega Pascal

E.S.C-Egyptian standard code

Psi- pound/square inch

$S F$ - silica fume

SP- superplastcizer

ASTM-American Society for testing and materials

PC-PLAST CRETE superplastcizer.

$C C$ - cements content

Fcr -The required average strength.

Fcu-Minimum compressive strength.

Fc-compressive strength

Ft-indirect tensile strength

$\mathrm{Fb}$-flexure strength

\section{REFERENCES}

[1] The Egyptian geological survey and mining authority - ministry of industry and mineral resources.

[2] (ACI). (1997). "State-of -the report on high-strength concrete" ACI 363R, Detroit.

[3] CEB-FIP, CEM-FIP model code 1990, Thomas Telford, London, 1993.

[4] (ACI). (1992). "State-of -the report on high-strength concrete" ACI 363R, Detroit.

[5] M. A. Rashid1; M. A. Mansur, M.ASCE2; and P. Paramasivam3 (2002)"Correlations between Mechanical Properties of High-Strength Concrete" Journal of Materials in Civil Engineering, National University of Singapore Vol. 14, No. 3, May-June. P.P 230-238.

[6] Logan,A.;Choi,W.;Miriam A.;Rizkalla S. and Zia P (2009)"Short-term mechanical properties of high strength concrete" ACI Material Journal, V.106, NO.5, September-October, PP.413-418.

[7] Erntory, H.C., and Shaklock, B.W.(1954)," design of high strength concrete mixes", proceeding of a symposium on mix design and quality control of concrete, cement and concrete association,London,may,pp.55-65.

[8] Li, Q. and Ansari,F.(2000) " high strength concrete in uniaxial tension " ACI materials journal, Vol 97, No 1 Junuary- Fabruary. PP.49-57.

[9] French, C.W., and Mokhtarzadeh. A., (1993). "High Strength Concrete: Effects of Material, Curing and Test Procedures on Short-Term Compressive Strength." ACI Material Journal, V.78, NO.14, MayJune.1981, PP.171-178.

[10] Aïtcin, P.C., Miao, B., Cook, W. D., and Mitchell. (1994). "Effects of Size and Curing on Cylinder Compressive Strength of Normal and High- Strength 
Concretes." ACI Material Journal, V.91, NO. 4, May-June.1981, PP.349-354.

[11] Anoglu,N.; Girgin,C.Z. and Anoglu,E. (2006)" Evaluation of ratio between splitting tensile strength and compressive strength for concretes up to 120 $\mathrm{MPa}$ and its application in strength criterion" ACI materials journal, V103 No 1 January-February. P.P 18-24.

[12] ECP 202-2001 (2005), Egyptian code of concrete laboratory and tests, Housing and Building Research Center, Cairo, Egypt. (inArabic)

[13] ASTM,C 136 1998," Standard Test Method for Sieve Analysis of Fine and Coarse Aggregates1 " annual book of ASTM standers, vol 04.02 and 04.03.

[14] ASTM,C 127 1998," Standard Test Method for Specific Gravity and Absorption of Coarse Aggregate1 " annual book of ASTM standers, vol 04.02 and 04.03.

[15] ASTM, C192 1998," Standard Practice for Making and Curing Concrete Test Specimens in the Laboratory1" annual book of ASTM standers, vol 04.02 and 04.03. 